\title{
MODEL MANAJEMEN KARIR MANAJER DAN KARYAWAN MASA DEPAN*)
}

\author{
Miswanto \\ STIE YKPN Yogyakarta
}

\begin{abstract}
Abstrak
Perubahan bisnis dan ekonomi yang sedang dan akan terjadi berdampak pada dunia kerja, salah satunya pada peranan manajer dan karyawan sebagai professional dan cara bagaimana mereka mengelola karirnya. Perusahaan membutuhkan model manajemen karir yang align people management with managing the business. Perusahaan dapat mengambil peran melalui praktik manajemen karir organisasional yang diarahkan agar tercipta perbaikan perjanjian kerja dan penumbuhan career-resilient workforce. Manajer dan karyawan harus professional mengantar diri mereka sendiri untuk mampu bersaing meraih masa depan dengan menerapkan paradigma strategi karier yang terdiri dari: (1) bagaimana strategi menghadapi tantangan bersaing, (2) bagaimana strategi mendapatkan masa depan, (3) bagaimana strategi memobilisasi masa depan, dan (4) bagaimana strategi untuk tiba paling dulu di masa depan.
\end{abstract}

Kata kunci: Strategi karier, bisnis, dan profesional

PENDAHULUAN

Perubahan bisnis dan ekonomi yang begitu besar sedang dan akan terjadi di seluruh dunia disertai dengan continuing job dislocation, greater insecurity, job requirement yang lebih besar (Kanter, 1995). Perubahan tersebut benar-benar mengubah dunia kerja. Tidak hanya permintaan pasar terhadap keahlian-keahlian dan bidang karir tertentu yang berubah, tetapi juga peranan manajer dan karyawan sebagai professional dan cara bagaimana mereka mengelola karirnya.

Agar lebih mudah mengikuti pembahasan dalam makalah ini, perlu dijelaskan dari awal pengertian karir. Karir adalah serangkaian pekerjaan yang dimiliki seseorang selama masih mampu aktif melakukan pekerjaan (Mondy, Noe, and Premeaux, 1993). Untuk mengelola karir, manajer dan karyawan membutuhkan manajemen karir. Manajemen karir adalah suatu proses untuk membuat yakin bahwa organisasi akan mempunyai orang yang tepat, dengan keahlian (skill) yang tepat pada waktu yang tepat, dan semua anggota organisasi saling membantu untuk mencapai sesuatu yang dianggap tepat (Mayo, 1992, p. 37).

Dalam makalah ini penulis akan membahas model manajemen karir yang dapat mengantisipasi permasalahan-permasalahan akibat adanya era globalisasi, liberalisasi perdagangan, deregulasi, dan kemajuan

*) Pernah diterbitkan pada Jurnal Siasat edisi Th. I Vol. 4 Mei, 1997. 
teknologi, sehingga manajer dan karyawan mampu meraih masa depan. Urut-urutan pembahasannya, pertama akan menguraikan bagaimana perubahan struktur organisasi berpengaruh terhadap model manajemen karir. Pembahasan kedua akan menguraikan improvement model manajemen karir. Pembahasan terakhir adalah bagaimana paradigma strategi baru perusahaan menopang model manajemen karir yang mampu mengantar manajer dan karyawan meraih masa depan.

\section{PERUBAHAN STRUKTUR ORGANISASI}

Perubahan bisnis dan ekonomi yang begitu besar yang sedang dan akan terjadi di seluruh dunia memaksa perusahaan untuk merombak struktur organisasi tradisional (Cabrera, 1990). Perombakan struktur organisasi, yang berupa: perubahan proporsi karyawan antara pekerja (manajer dan karyawan) tetap dan tidak tetap dan perubahan dari sistem hirarkhi ke sistem jaringan sangat berpengaruh pada manajemen karir. Dengan adanya pengaruh dari perubahan kedua faktor tersebut memicu manajer dan karyawan untuk mencari-cari model manajemen karir yang mampu mengantar meraih masa depan.

\section{Proporsi Pekerja}

Secara tradisional, para pemilik perusahaan memandang para pekerja (manajer dan karyawan) sebagai bagian tetap dari arsitek organisasional dan berasumsi bahwa mereka harus menambah pekerja secara proporsional sesuai dengan pertumbuhan bisnis. Ketidakstabilan ekonomi yang sedang dan akan terjadi telah memaksa perusahaan untuk mengkaji kembali asumsi ini dan mulai memandang pekerja sebagai biaya variable daripada sebagai biaya tetap.

Pada masa yang akan datang, tekanan-tekanan biaya terus berlanjut dan kebutuhan untuk cepat respon terhadap pasar memaksa perusahaan membangun pekerja professional yang benar-benar fleksibel dan cost-effective. Struktur organisasi organisasional tradisional lebih banyak mempekerjakan pekerja tetap, sedangkan struktur organisasi baru (masa depan) proporsi pekeja tetap lebih sedikit daripada pekerja tidak tetap. Struktur organisasi baru tersebut lebih fleksibel daripada struktur organisasi tradisional. Dalam struktur organisasi pekerja dibedakan dalam tiga kelompok: pekerja inti, pekerja suplemen, dan fungsi-fungsi pekerjaan outsourced.

1. Pekerja Inti (Core Employee).

Dalam struktur organisasi baru fungsi-fungsi critical job akan ditopang oleh para pekerja inti yang relatif kecil, bersifat tetap, dan mempunyai multiple skill yang tinggi yang memungkinkan mereka menangani berbagai macam pekerjaan. 
2. Pekerjaan Suplemen

Dalam struktur organisasi baru, sebagian besar perusahaan terdiri atas pekerja supelemen, yang bisa ditambahkan ataupun dikurangi dengan cepat sesuai dengan kebutuhan. Para pekerja tersebut dipekerjakan melalui kontrak secara temporer sesuai dengan jadwal kerja. Pada masa sekarang dan yang akan datang ada kecenderungan peningkatan dramatis berupa: ahli teknis, manajer menengah, dan bahkan manajer puncak dikontrak sebagai pekerja suplemen.

3. Fungsi-fungsi Pekerjaan Outsourced

Perusahaan-perusahaan akan menggunakan outsourcing lebih banyak dan lebih bersifat strategis. Outsourcing dari pekerja local biasanya pekerjaan yang bersifat labor-intensive job dan bernilai tambah (valueadded) rendah. Outsourcing untuk pekerjaan memiliki nilai tambah tinggi biasanya dari perusahaan nasional atau global (Kanter, 1995, p. 150). Perusahaan-perusahaan pada masa lalu menggunakan outsourcing sebagai proses yang terpisah dari proses penyelesaian seluruh produksi dan fungsi-fungsi palayanan. Pada saat yang akan datang, perusahaan-perusahaan akan memperhatikan agen-agen outsourcing sebagai bagian yang terintegrasi dengan tim organisasi.

Model manajemen karir tradisional tidak sesuai lagi untuk diterapkan dalam struktur organisasi baru, yang menciptakan dunia pasar tenaga kerja baru. Bentuk perjanjian kerja antara pekerja dan perusahaan harus ditinjau kembali agar sesuai dengan perubahan pasar tenaga kerja yang baru tersebut. Gambar 1 menunjukkan perbedaan proporsi pekerja inti, tambahan, dan outsourcing antara struktur organisasi tradisional dan baru.

\section{Gambar 1.}

Perbedaan Proporsi Karyawan antara Struktur Organisasi Tradisional dan Baru

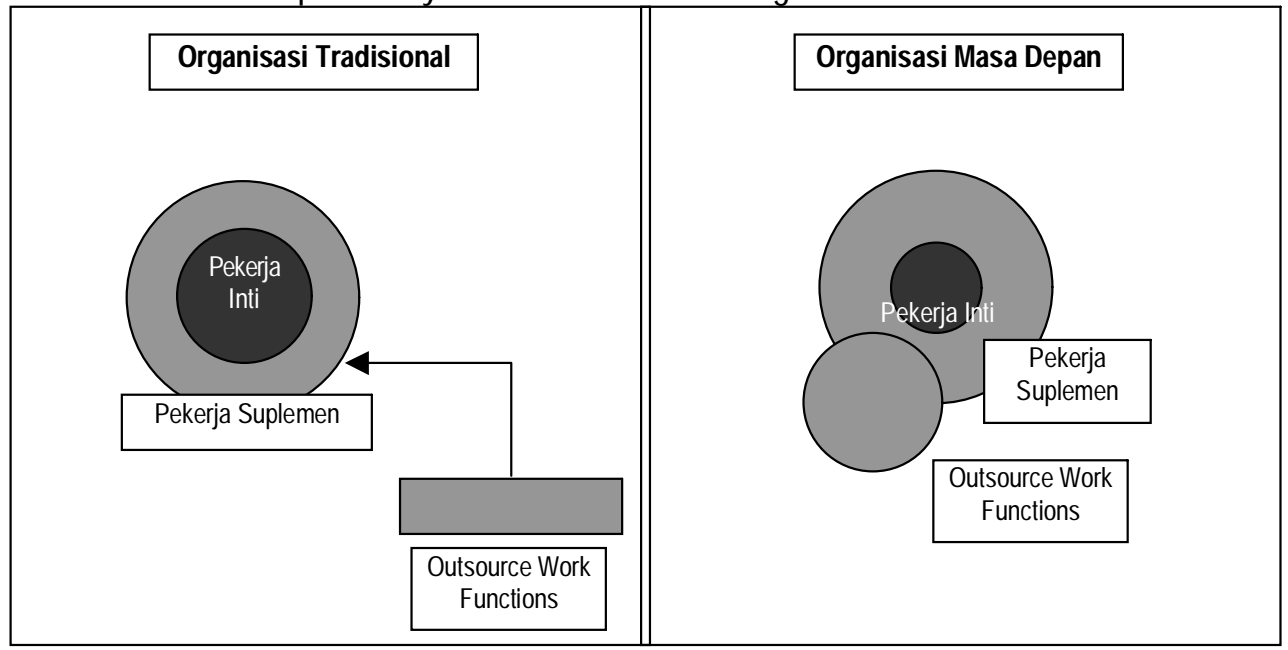




\section{Dari Hirarkhi ke Jaringan}

Perubahan struktur organisasi untuk menghadapi perubahan lingkungan bisnis saat ini dan yang akan datang selain mengubah proporsi pekerja juga mengubah sistem hirarkhi menjadi sistem jaringan. Salah satu penerapan terbaru sistem jaringan adalah pada jaringan professional (professional networking) dan manajemen karir. Beberapa perusahaan menggunakan jaringan untuk meneliti pelamar pekerjaan yang prospektif. Begitu juga para professional akan menggunakan jaringan untuk mencari pekerjaan baru, dan melakukan pemantauan lingkungan pekerjaan yang menyertai trend-trend industri dan perusahaan, yang secara langsung berpengaruh terhadap pekerjaan mereka.

\section{Improvement Model Manajemen Karir}

Improvement model manajemen karir adalah menciptakan model manajemen karir baru untuk menggantikan model manajemen karir tradisional. Dalam melakukan improvement model manajemen karir, manajer dan karyawan baru pengetahui: karakteristik model manajemen karir tradisional, model manajemen karir baru, peran perusahaan dalam model manajemen karir baru, peran perusahaan dalam model manajemen karir baru, pelatihan dan pengembangan, dan career strategist dalam masa transisi.

\section{KARAKTERISTIK MODEL MANAJEMEN KARIR TRADISIONAL}

Dengan adanya kecenderungan perusahaan melakukan perubahan struktur organisasi seperti yang sudah diuraikan di atas, model manajemen karir tradisional (disebut juga perencanaan karir tradisional) tidak sesuai lagi untuk dipergunakan, karena model tersebut menjadikan manajer dan karyawan sebagai perencana karir. Karakteristik-karakteristik perencana karir adalah: 1) berasumsi carerr path yang tetap, karena diasumsikan bahwa perubahan lingkungan bersifat gradual, incremental, dan dapat diprediksi, (2) keberhasilan karir diidentikkan dengan jumlah tropi atau penghargaan yang terkumpul, 3) berfokus pada tujuan jangka panjang yang tetap, 4) menciptakan suatu karir yang linier, yaitu kenaikan karir sesuai dengan tahapan jenjang jabatan dalam struktur organisasi, 5) meyakini bahwa tujuan tergantung pada usia, 6) mengembangkan rencana yang kaku dengan pengembangan tujuan yang tidak pernah diuji ulang, 7) arah kemajuan melalui external career markers, dan 8) berasumsi bahwa organisasi akan merencanakan dan mengarahkan karir dan mereka menggantungkan karirnya pada perusahaan (Barner, 1994). 


\section{MODEL MANAJEMEN KARIR BARU}

Lingkungan pekerjaan yang berubah cepat tidak lagi mendukung model perencanaan karir tradisional. Dalam dunia bisnis yang mudah berubah ini, banyak perubahan yang jatuh bangun, banyak industri yang mengalami kemunduran, dan banyak manajer dan karyawan tradisional gagal memperbaharui keahliannya.

Untuk sukses di tempat kerja di masa yang akan datang, manajer dan karyawan harus menciptakan sebuah model baru manajemen karir, manajer dan karyawan tidak lagi sebagai perencana karir, melainkan sebagai career strategist. Berikut ini adalah karakteristik-karakteristik career strategist (Barner, 1994).

1. Menggambarkan carerr path yang terputus dan berubah. Dengan perubahan lingkungan yang tidak dapat diprediksi, perusahaan tidak dapat menjamin stabilitas kelangsungan corporate career path atau security of job karyawan.

2. Mengidentikkan keberhasilan karir dengan customer value.

3. Berfokus pada tujuan ganda: berjangka pendek dan panjang.

4. Mengembangkan rencana multidimensional, beberapa tujuan dikelompokkan untuk memenuhi kebutuhan karir dalam hidup seseorang.

5. Meyakini bahwa tujuan tidak tergantung pada usia, sehingga mereka bebas menjalankan cara-cara baru pada setiap langkah.

6. Menciptakan rencana yang fleksibel, dengan tujuan yang terus dikaji ulang dan memungkinkan adanya rencana situasional.

7. Arah kemajuan disesuaikan dengan keputusan karir yang berfokus pada customer.

8. Berasumsi bahwa mereka akan merencanakan dan mengarahkan karir sendiri, tidak menggantungkan diri terhadap perusahaan tempat mereka bekerja.

\section{PERAN PERUSAHAAN DALAM MODEL MANAJEMEN KARIR BARU}

Manajemen karir organisasional (organizational career management), disingkat MKO dapat didefinisikan sebagai aktivitas dan kesempatan organisasi (perusahaan) berperan untuk membantu menjamin agar mereka (manajer dan karyawan) dapat memenuhi (atau lebih memenuhi) kebutuhannya di masa depan. Menurut Stumpf dan Hanrahan (1983), praktik MKO meliputi: perencanaan karir, career path, aktivitas pelatihan dan pengembangan, program pengembangan sasaran (target), promosi dari dalam, kebijakan staffing formal, criteria promosi standar, assessment center, job posting, job matching, career counseling, autplacement counseling, dan mentor-protégé relationship. Praktik-praktik dilakukan secara tepat, dengan biaya yang efektif (cosst effective), dan dengan mempertim- 
bangkan faktor-faktor: tersedianya tenaga kerja, kondisi keuangan, values manajemen puncak, lingkngan social ekonomi dan industri, dan strategi bisnis perusahaan.

Ada beberapa manfaat dari praktek MKO yang dapat diperoleh oleh perusahaan, yaitu: 1) meminimumkan perputaran pekerja kunci, 2) mendorong perputaran bagi pekerja yang tidak produktif, 3) mengevaluasi dan mengembangkan keahlian untuk berperan pada masa yang akan datang, 4) mengembangkan secara umum orientasi nilai korporasi (corporate values), 5) menjaga kontinuitas, 6) mengurangi persaingan yang tidak sehat, 7) menciptakan image korporasi yang positif, dan 8) menjaga kebijakan manajerial (Stumpf and Hanrahan, 1983).

Dalam melaksanakan MKO, perusahaan harus berperan menciptakan dan menopang manajer dan karyawan sebagai career strategist. Perusahaan dapat mengambil peran melalui praktik-praktik MKO yang diarahkan agar tercipta: 1) perbaikan perjanjian kerja dan 2) penumbuhan career-resilient workforce.

1) Perbaikan Perjanjian Kerja

Perjanjian kerja baru bersifat memperbaiki perjanjian kerja lama antara perusahaan dan pekerja. Karakteristik perjanjian baru adalah: 1) berfokus pada employability, tidak lagi berfokus pada employement, 2) membagi tanggung jawab antara perusahaan dan pekerja untuk menjaga, bahkan meningkatkan agar individu dapat dipekerjakan (employability) di dalam dan di luar perusahaan, dan 3) perusahaan memberikan peluang individual untuk dapat berkembang agar mempunyai produktivitas kerja yang tinggi (Haywood, 1993).

Perjanjian kerja baru juga mempunyai karakteristik: 1) mendorong pekerja bertanggung jawab untuk mengelola karir mereka sendiri, 2) menciptakan perusahaan yang bertanggung jawab dengan memberikan kepada pekerja: alat, open environtment, dan peluang-peluang untuk melakukan pengembangan dan penilaian keahlian mereka, dan 3) mendorong manajer pada semua tingkat agar mereka care terhadap karyawan (Waterman, Waterman, and Collard, 1994).

2) Penumbuhan Career-Resilient Workforce

Perusahaan menumbuhkan suatu career-resilient workforce (CRW), yaitu suatu kelompok karyawan yang tidak hanya mau melaksanakan lifelong learning, tetapi juga selalu siap introspeksi diri untuk selalu siap menghadapi perubahan, memiliki tanggung jawab terhadap manajemen karir diri mereka sendiri, dan mempunyai komitmen pada kesuksesan perusahaan (Waterman, Waterman, and Collard, 1994). CRW berarti juga: 1) setiap individu sadar terhadap pengetahuan, kemampuan, dan keahlian yang dimiliki, kekuatan dan kelemahannya, mempunyai rencana untuk meningkatkan kinerjanya, dan berusaha 
untuk dapat dipekerjakan dalam jangka panjang, 2) setiap karyawan mempunyai willingness dan kemampuan untuk cepat tanggap dan fleksibel terhadap perubahan bisnis yang dibutuhkan, dan 3) penggerakan hubungan saling menguntungkan (win-win relationship) antara perusahaan dan karyawan.

CRW memberikan karyawan wewenang untuk meningkatkan personality yang baik dan memperluas: pengetahuan, kemampuan, dan keahlian mereka sehingga mereka tetap kompetitif di pasar kerja. CRW membutuhkan perubahan perilaku dan values: 1) karyawan merasa bernilai, percaya, dan respek terhadap semua anggota perusahaan, dan merasa sebagai bagian dari mereka, 2) karyawan harus memiliki multiple skill, agar mudah menembus functional boundaries, 3) karyawan lebih menyadari bahwa tujuan perusahaan adalah memberikan customers value berupa barang dan jasa, jika perusahaan tidak mampu memberikan customers value, tidak satupun karyawan yang memiliki pekerjaan, 4) hubungan baru antara perusahaan dan karyawan diubah dari tradisional parent-child relationship menjadi adult-adult relationship.

\section{PELATIHAN DAN PENGEMBANGAN}

Manajemen karir adalah salah satu elemen dari manajemen kinerja. Elemen lain manajemen kinerja adalah: pemilihan dan penempatan manajer dan karyawan, pelatihan dan pengembangan, penilaian kinerja, dan pemberian kompensasi (Miswanto, 1996). Elemen-elemen manajemen kinerja saling berkaitan satu sama lain. Pelatihan dan pengembangan adalah elemen manajemen kinjerja yang paling terkait dengan manajemen karir. Di samping itu juga, pelatihan dan pengembangan merupakan salah satu elemen dari praktik manajemen karir organisasional. Oleh karena itu, pelatihan dan pengembangan harus dilakukan untuk menciptakan manajer dan karyawan sebagai career strategist (Crampton, Hodge, and Matwani, 1994).

Dalam menghadapi globalisasi ekonomi saat ini dan yang akan datang, manajer dan karyawan sebagai career strategist membutuhkan sistem pelatihan dan pengembangan professional yang mampu menghasilkan sumber daya manusia professional kelas dunia. Pelatihan dan pengembangan professional tradisional tidak lagi efektif untuk dipergunakan menghasilkan sumber daya manusia professional yang dibutuhkan oleh perusahaan. Oleh karena itu, pelatihan dan pengembangan professional tradisional ditinggalkan digantikan dengan pelatihan dan pengembangan professional baru, misalnya menggunakan total quality management.

Dalam menghadapi tantangan dunia global, pelatihan dan pengembangan tersebut harus mengarahkan manajer dan karyawan untuk melaku- 
kan peninjauan kembali mindset. Mindset lama (mindset terkotak) ditinggal dan diganti dengan mindset baru (mindset global) (Miswanto, 1996).

Mindset adalah sikap mental yang dapat dibentuk melalui pelatihan, pengembangan, dan pengalaman. Mindset merupakan landasan orang dalam berperilaku. Mindset memiliki komponen paradigma, core beliefs, dan core values yang secara gabungan akan membentuk sikap mental seseorang dalam menafsirkan, memikirkan, dan bertindak dalam lingkungan tertentu (Mulyadi, 1996, h. 6-7).

Peninjauan kembali mindset menunjukkan peninjauan cara melihat diri sendiri, dunia sekitar, dan dunia yang akan datang. Peninjauan kembali mindset berarti juga peninjauan kembali paradigma, core beliefs, dan corealues. Dengan demikian, mindest baru tersebut dapat dipergunakan oleh manajer dan karyawan untuk melakukan improvement berkelanjutan dalam memahami dan melaksanakan pekerjaannya dalam memasuki lingkungan global.

Mindset global dapat menciptakan manajer dan karyawan sebagai keunggulan kompetitif global (global competitive advantage). Keunggulan kompetitif global merupakan jantung kinerja perusahaan di pasar kompetitif global (Porter, 1990).

Menurut Rhinesmith (1995), ada enam mindset global yang harus diadopsi, yaitu: 1) menggerakkan pandangan ke arah yang lebih besar, 2) menyeimbangkan paradoks, 3) meyakini proses di atas struktur, 4) menghargai perbedaan-perbedaan, 5) mengelola perubahan, dan 6) melakukan lifelong learning (Rhinesmith, 1995).

Setelah mengikuti pelatihan dan pengembangan professional baru dan memiliki mindset global, maka manajer dan karyawan akan mampu untuk mempersiapkan diri sebagai career strategist dalam menghadapai tantangan yang terjadi. Langkah-langkah yang harus dilakukan dalam menghadapi tantangan yang terjadi adalah (Barner, 1994):

1. Manajer dan karyawan harus mengikuti trend-trend dunia bisnis dan ekonomi yang mungkin memberikan kesempatan berkembang terhadap perjalanan karir yang potensial.

2. Manajer dan karyawan mengembangkan suatu pandangan atau gambaran secara jelas yang berdasarkan pada karir dan kebutuhan gaya hidup (life style).

3. Manajer dan karyawan harus melakukan benchmark terhadap keahlian yang dimiliki dengan menggunakan keahlian terbaik dalam bidang yang sama di masa sekarang dan yang akan datang.

4. Manajer dan karyawan membentuk contingency plan agar mampu berkarir dalam kondisi yang terus berubah dan tidak pasti.

5. Manajer dan karyawan mengembangkan portable skill, tidak hanya mengandalkan keahlian-keahlian kontekstual. Portable skill adalah 
keahlian yang dapat ditransfer dengan mudah pada lingkungan kerja lain yang berbeda. Portable skill diantaranya berupa: managerial skill, intellectual skill, communication skill, dan interpersonal skill. Sebaliknya, keahlian kontekstual adalah keahlian yang relatif tidak dapat ditransfer yang pada lingkungan kerja lain yang berbeda.

\section{CAREER STRATEGIST DALAM MASA TRANSISI}

Transisi berarti periode selama individu menyesuaikan diri dengan keadaan dan atau peran dalam kerja yang berbeda. Promosi dan rotasi pekerjaan menimbulkan adanya masa transisi. Periode transisi ini tidak lepas dari perubahan pekerjaan maupun peran seseorang. Dalam menghadapi perubahan bisnis dan ekonomi yang sedang dan akan terjadi, perubahan pekerjaan dan peran manajer dan karyawan dalam karyawan akan selalu terjadi, sehingga cenderung sering terjadi masa transisi. Pada transisi ini, pengalaman kerja sangat diperlukan dan juga pendatang baru perlu untuk mempersiapkan pemikiran, perasaan, dan perilaku yang berkaitan dengan pekerjaan. Kemampuan adaptasi dalam masa transisi ini sangat menentukan kesuksesan seseorang dalam melaksanakan pekerjaannya yang baru.

Karena berbagai alas an, manajemen transisi sangatlah diharuskan sebagai bagian dari pengembangan karir, pelatihan dan pengembangan, dan pembimbingan. Dengan memahami transisi, supervisor dan manajer dapat membantu untuk mengintegrasikan dan mengembangkan karir terhadap karyawan yang menghadapi masa transisi. Seseorang yang dapat memahami dengan baik realita transisi akan lebih baik dalam merencanakan dan menyesuaikan pada kondisi baru di pekerjaan yang baru.

Berikut ini merupakan langkah-langkah untuk membantu pendatang baru dan orang yang memasuki masa transisi agar dapat memahami lebih baik dan mengelola transisi, baik dalam pekerjaan baru maupun pekerjaan yang akan datang (Louis, 1982, p. 321).

1. Memahami pengalaman transisi tertentu.

Biasanya timbul perasaan tertentu pada masa transisi, misalnya perasaan bingung karena segala sesuatu serba baru dan dapat terjadi secara bersamaan. Perasaan terkejut timbul terhadap hal-hal yang tidak dapat dihindari. Pendatang baru ini perlu mengetahui dalam masa transisinya apakah kebiasaan-kebiasaan lama sudah tidak sesuai lagi dengan kondisi baru.

2. Mendefinisikan transisi yang ideal.

Pendatang baru perlu mengetahui tugas-tugas tertentu, orangorangnya, dan informasi lain selama periode awal pekerjaannya.

3. Mendefinisikan situasi transisi. 
Dalam menganalisis situasi transisi ini perlu mengetahui: 1) pendatang baru, 20 atasan, 3) pendahulunya, 4) pekerja kunci yang lain, 5) posisi baru, dan 6) perubahan pekerjaan.

4. Mencari problem pokok yang potensial pada masa transisi dan yang dialami oleh pendatang baru.

5. Menyelesaikan tugas-tugas transisi penting.

Dengan menggunakan portable skill dan multiple skill, pendatang baru harus dapat menyelesaikan beberapa tugas dasar agar dapat menjadi anggota secara penuh dari suatu departemen ataupun organisasi. Tugas-tugas tersebut antara lain: 1) mampu dalam menyelesaikan tugastugas dasar, 2) membangun image dan identitas dalam berperan, 3) membangun hubungan, 4) memetakan (map) pemain-pemain yang relevan, 5) menempatkan diri dalam tugas dan jaringan (network), 6) mempelajari bahasa setempat dan menerima simbol-simbol yang biasa digunakan oleh kelompok kerja dan organisasi, 7) menilai bagaimana agar pekerjaan dapat dilaksanakan dengan baik dan menilai bagaimana keterkaitannya dalam unit.

6. Menyusun prioritas berdasarkan: analisis situasi, pengetahuan mengenai tugas-tugas penting, dan apresiasi terhadap preferensi individu.

7. Memilih strategi, berdasarkan pada hasil yang diperoleh dari langkah keenam di atas.

Pendatang baru yang memperhatikan langkah-langkah ini dapat: menyusun prioritas lebih baik dalam menyelesaikan masalah, mencari dan menyusun informasi, memahami pengalaman pribadinya, dan mengelola proses transisi lebih cepat. Dengan manajemen transisi yang baik, supervisor dapat membantu untuk menyediakan transisi yang efektif dan efisien pada pendatang baru dan supervisor juga dapat mengembangkan mereka agar menjadi anggota organisasi yang produktif.

\section{PARADIGMA STRATEGI BARU MERAIH MASA DEPAN}

Lingkungan yang berubah drastic membuat persaingan masa yang akan datang berbeda dengan persaingan saat ini. Persaingan meraih masa depan adalah persaingan untuk menciptakan dan mendominasi peluang-peluang yang muncul. Di samping itu, industri-industri yang sekarang ada akan berubah total. Perubahan-perubahan tersebut membawa peluang karir manajer dan karyawan untuk mengubah produk, jasa, dan industri yang ada. Yang dibutuhkan manajer dan karyawan untuk membawa perusahaan agar dapat sampai ke depan paling dulu, diperlukan empat hal: 1) pemahaman mengenai bagaimana persaingan meraih masa depan itu berbeda, 2) proses untuk menemukan dan memperoleh wawasan tentang 
peluang-peluang hari esok, 3) kemampuan untuk menyemangati anggota organisasi dari atas sampai bawah guna menempuh perjalanan panjang dan sulit menuju masa depan, dan 4) kemampuan untuk mendahului pesaing dan tiba di masa depan paling dulu, tanpa memikul risiko-risiko yang tidak perlu (Hamel and Prahalad, 1994).

Untuk membantu manajer dan karyawan sebagai career strategist dalam membayangkan masa depan dan menciptakannya, manajer dan karyawan harus menggunakan strategi bersaing meraih masa depan. Karena lingkungan bisnis dan dan ekonomi terus berubah dibutuhkan paradigma strategi baru. Paradigma adalah lensa yang digunakan untuk memandang dunia (Mulyadi, 1996).

Paradigma strategi baru yang dapat digunakan oleh career strategist untuk meraih masa depan secara ringkas dapat dilihat pada Tabel 1 dan jika dijabarkan sebagai berikut:

\section{Tantangan Bersaing}

Untuk menghadapi tantangan bersaing, paradigma strategi yang digunakan manajer dan karyawan adalah:

- Reengineering Proceeses dan Regenerating Strategies. Karena restrukrisasi sering menemui jalan buntu, perusahaan beralih melakukan reengineering processes. Reengineering processes bertujuan menghilangkan yang tidak perlu dan mengarahkan setiap proses di perusahaan untuk: kepuasan customer, pengurangan siklus waktu, dan kualitas secara total. Di banyak perusahaan, reengineering processes lebih menyangkut pengejaran kemajuan - karena mereka merasa tertinggal dari para pesaingnya - dan bukan merebut posisi terdepan. Untuk merebut posisi terdepan, perusahaan harus melakukan regenerasi strategi (regenerating strategies). Oleh karena itu, perusahaan tidak hanya melakukan reengineering processes tetapi juga melakukan regenerating strategies.

- Transformasi Organisasi dan Transformasi Industri. Bagi kebanyakan perusahaan rencana transformasi organisasi lebih bersifat reaktif daripada proaktif. Keberhasilan mengelola tugas transformasi organisasi dapat membuat suatu perusahaan ramping dan tangkas, tetapi tidak dapat membuat perusahaan menjadi perintis industri. Untuk menjadi leader, perusahaan harus memimpin proses transformasi industri. Oleh karena itu, perusahaan tidak hanya melakukan transformasi organisasi, tetapi juga melakukan transformasi industri.

- Bersaing untuk Market Share dan Opportunity Share. Persaingan masa depan merupakan persaingan memperebutkan opportunity share daripada memperebutkan market share. Memaksimumkan opportunity share masa depan adalah suatu yang harus diraih oleh perusahaan 
disamping juga market share. Oleh karena itu, perusahaan tidak hanya bersaing untuk memperoleh market share, tetapi juga untuk memperoleh opportunity share.

\section{Menemukan Masa Depan}

Untuk menemukan masa depan, paradigma strategi yang digunakan manajer dan karyawan adalah:

- Strategi Sebagai Learning Processes dan Forgetting Processes. Meskipun sangat popular, learning organization adalah baru hanya setengah dari langkah penyelesaian. Yang sama pentingnya adalah menciptakan "unlearning" organization. Sebagai contoh, anak-anak melakukan learning processes lebih cepat daripada orang dewasa, salah satu alasannya adalah anak-anak tidak banyak memiliki sesuatu yang harus dilupakan. Untuk menciptakan masa depan, perusahaan harus melupakan setidak-tidaknya sebagian masa lalunya (misalnya berupa kebiasaan-kebiasaan) yang menghambat sukses masa depan. Jika perusahaan membangun masa lalu, godaan untuk melestarikannya sangat besar. Perusahaan harus bekerja keras untuk melakukan forgetting processes seperti halnya melakukan learning processes. Oleh karena itu, perusahaan menggunakan tidak hanya strategi sebagai learning processes, tetapi juga sebagai forgetting processes.

- Strategi Sebagai Pemosisian ke Depan dan Wawasan. Strategi sebagai pemosisian, yang berarti menempatkan perusahaan dalam sebuah lingkungan, adalah salah satu strategi umum dilakukan oleh perusahaan (Mintzberg, Quinn, and Voyer, 1995). Untuk mencapai masa depan, terutama manajer puncak harus menyadari bahwa keberhasilan masa lalu dan saat sekarang tidak menjamin keberhasilan masa depan. Hambatan mencapai masa depan, bukanlah masa depan itu tidak dapat diketahui, melainkan masa depan itu berbeda. Wawasan ke depan berasal dari keinginan yang sungguh-sungguh untuk membuat perbedaan-perbedaan dalam kehidupan manusia. Landasan wawasan ke depan diantaranya: melepaskan diri dari myopia konsep produk yang ada, mengembangkan rasa ingin tahu yang mendalam, berani berspekulasi, melihat masa depan dengan banyak ragam lensa, menjadi penentang, dan empati terhadap kebutuhan manusia. Oleh karena itu, perusahaan tidak hanya menggunakan strategi untuk mendapatkan posisi optimum bagi perusahaan di pasar-pasar yang sudah ada, tetapi juga strategi sebagai wawasan (foresight).

- Rencana Strategik dan Arsitektur Strategik. Strategi yang diperlukan lebih daripada sekedar rencana tahunan atau lima tahunan yang bersifat incremental, yaitu diperlukan suatu arsitektur strategic yang memberikan blue-print untuk membangun kompetensi-kompetensi yang 
diperlukan untuk mendominasi pasar masa depan. Manajer puncak sebagai arsitektur strategi harus mampu memimpikan suatu strategi yang belum pernah diciptakan dan mampu menciptakan blue-print untuk mengubah impian menjadi kenyataan. Jadi, perusahaan menggunakan tidak hanya rencana strategic, tetapi juga arsitektur strategik.

\section{Memobilisasi Masa Depan}

Untuk memobilisasi masa depan, paradigma strategi baru yang digunakan oleh manajer dan karyawan adalah:

- Strategi Sebagai Fit dan Strech. Suatu pandangan menunjukkan bahwa strategi tidak terlampau memikirkan kecocokan ketat antara tujuan dan sumber daya. Perusahaan lebih mementingkan penciptaan stretch goals yang menantang para manajer dan karyawan untuk mencapai apa yang tampak tidak mungkin. Niat strategis perusahaan hendaknya mencerminkan suatu ambisi yang membentang (stretch) jauh melampaui kapabilitas sumber daya dan perusahaan yang ada sekarang. Perusahaan menggunakan tidak hanya strategi sebagai fit, tetapi juga sebagai stretch.

- Strategi Sebagai Alokasi Sumber Daya dan Akumulasi Sumber Daya dan Leverage. Suatu pandangan bahwa strategi adalah lebih daripada sekedar alokasi sumber daya langkah ke berbagai proyek yang saling bersaing, yaitu strategi sebagai upaya untuk mengatasi kendala sumber daya melalui kegiatan-kegiatan kreatif tanpa mengenal akhir untuk mendapatkan daya ungkit sumber daya (resource leverage) yang lebih baik. Perusahaan yang mempunyai daya ungkit sumber daya lebih baik akan mampu bersaing lebih baik, walaupun sumber daya yang dimiliki terbatas.

\section{Tiba Paling Dulu di Masa depan}

Untuk tiba paling dulu di masa depan, paradigma strategi baru yang digunakan oleh manajer dan karyawan adalah:

- Bersaing dalam Struktur Industri yang Ada dan Masa Depan. Suatu pandangan bahwa perusahaan tidak hanya bersaing dalam batas-batas industri yang sudah ada, tetapi perusahaan bersaing untuk membentuk struktur industri masa depan.

- Bersaing untuk Product Leadership dan Core bertindak untuk mendahului global (global preemption) Competence Leadership. Suatu pandangan bahwa strategi persaingan tidak hanya untuk mendapatkan product leadership, tetapi juga strategi untuk mendapatkan core competence leadership. Kompetensi ini (core competence) adalah sekumpulan ketrampilan dan teknologi yang memungkinkan suatu perusahaan menyediakan manfaat tertentu kepada customer. Strategi me- 
mandang korporasi tidak hanya sebagai portfolio bisnis tetapi korporasi juga sebagai portfolio kompetensi.

- Bersaing Sebagai Single Entity dan Satu Koalisi. Suatu pandangan strategi yang menyadari bahwa persaingan sering kali terjadi tidak hanya antar bisnis secara individual (single entity), tetapi juga terjadi dalam dan antarkoalisi perusahaan.

- Memaksimumkan Rasio Produk Baru dan Rate of New Market Learning. Suatu pandangan strategi yang menyadari bahwa kegagalan produk seringkali tidak terelakkan, namun demikian, perusahaan harus memberikan kesempatan untuk melakukan learning tentang dimana persisnya sumber utama permintaan masa depan berada. Oleh karena itu, perusahaan tidak hanya memaksimumkan rasio produk baru yang sukses, tetapi juga memaksimumkan tingkat new market learning.

- Meminimumkan Saat Masuk Pasar dan Bertindak Mendahului Global. Suatu pandangan strategi yang menyadari bahwa untuk mendapatkan manfaat dari wawasan ke depan dan core competency leadership, perusahaan pada akhirnya harus mendahului pesaing-pesaing di pasar global. Perusahaan tidak hanya meminimumkan saat masuk pasar, tetapi juga meminimumkan saat untuk keluar pasar.

Tabel 1. Paradigma Strategi Baru

\begin{tabular}{|c|c|}
\hline & Tetapi Juga \\
\hline \multicolumn{2}{|c|}{ Tantangan Bersaing } \\
\hline Reenginering Processes & Regenerating strategies \\
\hline Transformasi Organisasi & Transformasi Industri \\
\hline Bersaing untuk Market Share & Bersaing untuk opportunity share \\
\hline \multicolumn{2}{|c|}{ Mendapatkan Masa Depan } \\
\hline Strategi sebagai learning process & Strategi sebagai forgetting processes \\
\hline Strategi sebagai positioning & Strategi sebagai foresight \\
\hline Rencana Strategik & Arsitektur strategi \\
\hline \multicolumn{2}{|c|}{ Memobilisasi Masa Depan } \\
\hline Strategi sebagai fit (kecocokan) & Strategi sebagai Strech \\
\hline Strategi sebagai resource allocation & Strategi sebagai resource accumulation and leverage \\
\hline \multicolumn{2}{|c|}{ Tiba Paling Dulu di Masa Depan } \\
\hline Bersaing dalam struktur industri yang ada & Bersaing untuk membentuk struktura industri masa depan \\
\hline Bersaing untuk product leadership & Bersaing untuk core competence leadership \\
\hline Bersaing sebagai single entity & Bersaing sebagai satu koalisi \\
\hline Memaksimumkan rasio produk yang baru sukses & Memaksimumkan tingkat new market learning \\
\hline Meminimumkan saat masuk pasar & $\begin{array}{l}\text { Meminimumkan waktu untuk bertindak global preemtion } \\
\text { (mendahului global) }\end{array}$ \\
\hline
\end{tabular}

\section{PENUTUP}

Perusahaan sekarang ini membutuhkan mode manajemen karir yang align people management with managing the business. Dengan memperhatikan karakteristiknya, model manajemen karir tradisional tidak 
lagi efektif untuk dipergunakan dalam perusahaan yang memasuki persaingan global. Oleh karena itu, model manajemen karir tradisional harus ditinggalkan dan digantikan dengan model manajemen karir baru. Dengan memperhatikan karakteristiknya, model manajemen karir baru sesuai dan efektif bagi perusahaan yang memasuki persaingan yang semakin ketat di pasar global.

Untuk melakukan improvement dalam berkarir, manajer dan karyawan harus disertakan dalam sistem pelatihan dan pengembangan berkelanjutan dengan diarahkan agar mereka memiliki mindset global. Sistem pelatihan dan pengembangan tersebut harus menggunakan pendekatan baru (misalnya total quality management) yang mampu mengantar manajer dan karyawan sebagai career strategist. Dalam improvement model manajemen karir, perusahaan dapat mengambil peran melalui praktik-praktik manajemen karir organisasional yang diarahkan agar tercipta 1) perbaikan perjanjian kerja dan 2) penumbuhan careerresilient workforce.

Masa yang akan datang persaingan antar perusahaan sangat ketat. Masa yang akan datang berbeda dengan masa lalu dan sekarang. Oleh karena itu, manajer dan karyawan harus professional mengantar diri mereka sendiri untuk mampu bersaing meraih masa depan. Untuk menopang keberhasilan manajer dan karyawan sebagai career strategist, manajer bersama semua anggota organisasi perusahaan harus menggunakan paradigma strategi baru. Paradigma strategi baru terdiri dari: 1) bagaimana strategi menghadapi tantangan bersaing, 2) bagaimana strategi mendapatkan masa depan, 3) bagaimana strategi memobilisasi masa depan, dan 4) bagaimana strategi untuk tiba paling dulu di masa depan. Dengan ditopang paradigma baru tersebut, model manajemen karir yang menganggap manajer dan karyawan sebagai career strategist akan mampu mengantar mereka meraih masa depan melebihi dari apa yang diharapkan.

\section{DAFTAR PUSTAKA}

Barner, Robert (1994), "The New Career Strategist: Career Management for the Year 2000 and Beyond," The Futurist, September-October, pp. 8-14. Cabrera, James C. (1990), "Proactive Career Management," Executive Excellence, September, pp. 17-18.

Casio, Wayne F. (1992), Managing Human Resource: Productivity, Quality of Work Life, Profit, Third edition, New York: McGrawhill, Inc.

Crampton, Suzanne M., John W. Hedge, and Jaideep G. Motwani (1994), "Diversity and Career Development Issues in the 90s," Supervision, June, pp. 6-9. 
Hamel, Gary and C.K. Prahalad (1994), Competing for the Future, New York: Harvard Business School Press.

Haywood, Bruce G. (1993), "Career Planning and Development," Hospital Material Management Quarterly, May, pp. 42-48.

Kanter, Rosabeth Moss (1995), Wor Class: Triving Locally in the Global economy, New York: Simon \& Schester.

Louis, Meryl Reis (1982), "Managing Career Transition: A Missing Link in Career Development," Improving, pp. 316-325.

Mayo, Andrew (1992), "A Framework for Career Management," Personnel Management, Vol. 23, pp. 36-39.

Mintzberg, Henry, James Brian Quinn, and John Voyer (1995), The Strategy Process, Englewood Cliffs: Prentice-Hall, Inc.

Miswanto (1996), "Perbaikan Berkelanjutan Manajemen Kinerja," Kajian Bisnis: STIE Widya Wiwaha, (Nopember), h. 16-29.

, (1996), "Pelatihan dan Pengembangan Profesional Menuju Kinerja Kelas Dunia," Makalah untuk Lomba Karya Tulis IImiah dalam Rangka Lustrum III STIE YKPN.

Mondy, R. Wayne and Robert M. Noe (1993), Human Resource Management, Fifth Edition, Singapore: Allyn and Baccon.

Mulyadi (1996), "Total Quality Management: Pergeseran Paradigma dalam Pengelolaan Perusahaan," Jurnal Akuntansi \& Managemen STIE YKPN, Edisi Februari, h. 5-18.

(1996), "TQM: Pengelolaan Pendidikan Tinggi Bisnis Dalam Lingkungan Bisnis Global," Materi Internship Dosen STIE YKPN.

Porter, Michael E. (1990), The Competitive Advantage of Nations, New York: The Freee Press: A Division of Macmillan, Inc.

Rhinesmith, Stephen H. (1995), "Open Door to a Global Mindset, "Training \& Development, May, pp. 35-43.

Stumpf, Stephen, A and Nancy, M. Hanrahan (1983), "Designing Organizational Career Management Practices to Fit Strategic Management Objectives," Improving, pp. 326-347.

Waterman, Robert H., Judith a. Waterman, and Besty A. Collard (1994), "Thowawrd a Career-Resilent Workforce," Harvard Business Review, July-August, p. 87-95. 